\title{
Improvisações formativas em encontros com professoras/es-formadoras/es
}

\author{
Marcia Regina Gobatto \\ Daniela Franco Carvalho
}

Resumo: A intencionalidade principal da pesquisa se deu no desejo de cartografar nossos movimentos formativos, enquanto doze professoras/es-formadoras/es do/com o Centro de Formação e Atualização dos profissionais da Educação Básica do estado de Mato Grosso (Cefapro/MT), movimentos estes que transbordam para tempos e espaços que vão além e aquém de seu território. Uma cartografia que buscou adentrar na movimentação molecular que tece o cotidiano, através de encontros. Encontros provocados pelo ritornelo, na intenção do desencadeamento da formação-ritornelo. Encontros que são composições de vida, um devir outro de nós mesmas/os, na tentativa de experimentar responder nossos questionamentos e angústias. Cartografia do acontecimento, do experimentar caminhos outros necessários para mover o pensamento e desencadear uma possível transformação da compreensão que temos hoje da palavra formação. Um movimento do caminhar com a formação, (re)inventando-a. Improvisação formativa.

Palavras-chave: Cartografia. Encontros. Formação. Ritornelo. Professoras/es-formadoras/es.

\section{Formative improvisations throughout meetings with teacher educators}

\begin{abstract}
The aim of this research is to plat the formative movements of twelve teacher educators at the Centro de Formação e Atualização dos profissionais da Educação Básica (Training and Updating Centre for Basic Education Teachers) from the state of Mato Grosso (Cefapro/MT). These movements overflow time and space from this side and from that of its territory. This cartography sought, through meetings, to enter the molecular movements that intertwine the everyday life. The meetings were caused by a ritornello, with a view to unleash the ritornello-training-process. These meetings are the work of life. They are a series of transformations of ourselves in an attempt to try to answer our inquiries and relieve our anxiety. They are the cartography of the happening, of the other necessary roads experienced to change thoughts and to unleash a possible transformation of the understanding we have nowadays about the words 'training process'. A movement to walk along with the teacher training process, re-inventing it. Formative improvisation.
\end{abstract}

Keywords: Cartography. Meetings. Training process. Ritornello. Teacher educators. 


\title{
(Com)posições iniciais
}

A intencionalidade principal deste estudo se deu no desejo de cartografar os diferentes movimentos formativos das/os professoras/es-formadoras/es ${ }^{1}$, que aconteceram com/no Centro de Formação e Atualização dos profissionais da Educação Básica do estado de Mato Grosso (Cefapro/MT ${ }^{2}$ ), mas que transbordaram para tempos e espaços que foram além e aquém de seu território. Uma cartografia é um mapa móvel que acompanha as paisagens e suas transformações. Latitudes e longitudes.

\begin{abstract}
Chama-se longitude de um corpo os conjuntos de partículas que lhe pertencem sob essa ou aquela relação, sendo tais conjuntos eles próprios partes uns dos outros segundo a composição da relação que define o agenciamento individuado desse corpo. [...] Chama-se latitude de um corpo os afectos de que ele é capaz segundo tal grau de potência, ou melhor, segundo os limites desse grau. A latitude é feita de partes intensivas sob uma capacidade, como a longitude, de partes extensivas sob uma relação (DELEUZE; GUATTARI, 2012, p. 44).
\end{abstract}

Assim, a presente cartografia se deu na tentativa de adentrar na movimentação molecular que tece o cotidiano das/os professoras/es-formadoras/es no/com o Cefapro/MT, através de encontros. Encontros entre velocidades e lentidões e afectos ${ }^{3}$, que buscaram ultrapassar o conceito, transbordar a forma da formação como a conhecemos, na tentativa de sair das hierarquizações e das classificações enclausuradas dentro desta palavra tão corroída na educação. Esta tentativa pediu para desnudarmo-nos, portanto não há codinomes, mas circunscrição de acontecimentos. Nossos encontros são composições de vida, um devir outro de nós mesmas/os na tentativa de responder questionamentos e angústias. De vivenciar e/ou experimentar caminhos outros, necessários para mover o pensamento e desencadear uma possível transformação da compreensão que temos hoje da formação. Um movimento do caminhar com a formação, (re)inventando-a.

$\mathrm{Na}$ busca do experimentável e do cartografável, questionamentos surgiram: que formação é essa que tanto nos angustia, que nos faz desejar fugir, mas que nos faz ficar?

\footnotetext{
${ }^{1}$ Professor/a-formador/a é a denominação atribuída às professoras e aos professores, das diferentes áreas do conhecimento, que atuam no Cefapro/MT.

${ }^{2}$ O Cefapro/MT é uma instituição ligada à Secretaria de Estado de Educação, Esporte e Lazer de Mato Grosso (Seduc/MT). Instituição esta responsável pela política de formação, sistematização e execução de projetos e programas da referida secretaria, bem como pelo desenvolvimento de parcerias com o Ministério da Educação (MEC), Secretarias Municipais de Educação (SME) e Instituições de Ensino Superior (IES).

3 “Afecto em Deleuze, ao contrário do afeto, é uma potência totalmente afirmativa. O afecto não faz referência ao trauma ou a uma experiência originária de perda, segundo a interpretação psicanalítica. O afecto, ao qual nada falta, exprime uma potência de vida, de afirmação, o que aproxima Deleuze de Spinoza: na origem de toda existência, há uma afirmação da potência de ser. Afecto é experimentação e não objeto de interpretação. Neste sentido, afecto não é a mesma coisa que afeto: o afecto é não-pessoal" (LINS, 2005, p. 1254).
}

Quaestio, Sorocaba, SP, v. 19, n. 2, p. 437-454, ago. 2017. 
Como transformar a formação em criação? Como desencadear uma formação que inclua a ética como princípio? Como permanecer no meio e criar uma nova formação?

No caminho escolhido, a ética é um cuidado permanente da singularidade e da potência de agir. Um esforço permanente de elevar a potência dos encontros, elevando assim o poder de afectar e ser afectada/o, transformando os encontros formativos em potência de agir, que se espalha como potência de pensar, como potência de provocar e convocar sensações, nos tornando mais potentes do que realmente somos. Sempre querendo escapar das codificações impostas, suscitando acontecimentos que fogem ao controle. Encontros que se imponham como resistência e reinvenção. Que se imponham como experimentação. (Re)existência.

\section{Cartografia formativa}

Os encontros tomados como acontecimentos se colocam aqui como um falar com nossos movimentos formativos. Um fazer com nossos movimentos formativos. Fomos à busca da formação como movimento de criação, da potência afirmativa da formação singular, que é também potência de preenchimento, potência de desejo. Com as potências convocadas, queríamos saber se havia a possibilidade de construir outros caminhos, que não aqueles das representações e dos modelos formatados que tanto nos angustiam. Como seria o mapa dessa formação? Que formação seria essa?

Também tínhamos ciência de que, mesmo desejando uma formação sem amarras, livre, nômade, sem ordenações, hierarquias ou condicionantes, era/é impossível uma ruptura total com a produção da subjetividade, pois estamos inseridas/os em uma sociedade composta por ideais universalistas, com poderes e saberes dominantes. Um lugar de difícil liberdade criativa.

O plano é infinito e podemos iniciá-lo de mil maneiras, sempre (re)compondo nossas relações entre velocidades e lentidões e afectos. Diante disso, a formação que buscamos foge da formatação e dos modelos prontos e se põe em movimento-ritornelo.

O ritornelo se define pela estrita coexistência ou contemporaneidade de três dinamismos implicados uns nos outros. Ele forma um sistema completo de desejo, uma lógica da existência ("lógica extrema e sem racionalidade"). Ele se expõe em duas tríades ligeiramente distintas. Primeira tríade: 1. Procurar alcançar o território, para conjurar o caos; 2. Traçar e habitar o território que filtre o caos; 3. Lançar-se fora do território ou se desterritorializar rumo a um cosmo que se distingue do caos. Segunda tríade: 1. Procurar um território; 2. Partir ou se desterritorializar; 3. Retornar ou se reterritorializar (ZOURABICHVILE, 2009, p. 95). 
A formação-ritornelo é uma circularidade, o constante movimento em busca do que se repete, mas que se repete ritmadamente produzindo a diferença. Assim nunca é um retorno do mesmo, mas uma constante chegada da/o estrangeira/o ou ao estrangeiro. Um eterno voltar para casa (território conhecido), o que corresponde ao retorno da/o estrangeira/o, pois já não somos mais as/os mesmas/os (primeira tríade); ou retornamos para uma casa ainda por vir (segunda tríade). Estes movimentos não se dão separadamente, acontecem todos ao mesmo tempo, sendo o primeiro movimento a construção dos territórios, os quais são formados por meios. Meios são nascidos do caos, mas contra o caos, pois são intensidades sempre na iminência da exaustão.

\footnotetext{
Um meio é um "bloco de espaço-tempo" à volta do centro frágil constituído pelo ritornelo, bloco de vibrações instável, prestes a submeter-se a um código, a uma regra (que o transforma em território), e em permanente passagem para outro meio (transcodificação ou transdução) (GIL, 2008, p. 127).
}

É nos meios que as ações acontecem, mas é nos ritmos que elas se movimentam e se transformam, produzindo diferenças. O ritmo faz a conexão entre os meios e promove a transcodificação; ocorre no entre, entre-dois, entre-dois-meios. É aqui, no espaço intervalar, no vazio, que a diferença é produzida, por isso o ritmo é o "Desigual ou o Incomensurável, sempre em transcodificação", (DELEUZE; GUATTARI, 2012, p. 125) transformando, articulando e integrando elementos heterogêneos em um único pulsar.

Um território é formado por componentes de meios ritmados, ou seja, uma qualidade expressiva. Uma marca. Uma placa. A qualidade advém do meio e a expressão do ritmo "A territorialização é um ato do ritmo devindo expressivo, ou dos componentes de meio devindo qualitativos. A marcação de um território é dimensional, mas não é uma medida, é um ritmo" (DELEUZE; GUATTARI, 2012, p. 128).

Essa marca qualitativa é a assinatura do território, de um domínio, que nada tem de pessoal, mas pode ser utilizada pelas pessoas como estandarte, bandeira, placa que marca nosso domínio, nossa casa. Porém essa assinatura também está em movimento e vai devir estilo. $\mathrm{O}$ estilo nasce das relações móveis entre as qualidades expressivas e as matérias de expressões "De um lado, as qualidades expressivas estabelecem entre si relações internas que constituem motivos territoriais [...]. Por outro lado, as qualidades expressivas entram também em outras relações internas que fazem contrapontos territoriais” (DELEUZE; GUATTARI, 2012, p. 131). 
As relações que as qualidades expressivas estabelecem internamente, com seus impulsos; ou externamente, com as circunstâncias, geram uma autonomia de expressão, que devém estilo. Esta autonomia de expressão, este autodesenvolvimento, é estilo; marcas que definem um território, um domínio, marcas que lutam com as forças que batem à sua porta, por isso também "são linhas de variação contínua" (GIL, 2008, p. 131), que deslizam na esteira das linhas de fuga que cortam esse mesmo território. Os territórios já nascem com uma linha de errância, já em um movimento de desterritorialização, de abertura, mesmo que seja para reterritorializar mais tarde.

\begin{abstract}
Ora se vai do caos a um limiar de agenciamento territorial: componentes direcionais, infra-agenciamento. Ora se organiza o agenciamento: componentes dimensionais, intra-agenciamento. Ora se sai do agenciamento territorial, em direção a outros agenciamentos, ou ainda a outro lugar: interagenciamento, componentes de passagem ou até de fuga. E os três juntos. Forças do caos, forças terrestres, forças cósmicas: tudo isso se afronta e concorre no ritornelo (DELEUZE; GUATTARI, 2012, p. 124).
\end{abstract}

As relações rítmicas são as responsáveis pelo interagenciamento, pois pelo vazio do entre, abre canais com as forças cósmicas, o que provoca a desterritorialização. Assim entendemos que nossos movimentos formativos com o Cefapro/MT, ou a formação propriamente dita, são blocos de forças vivas, que podem ser capturadas e transformadas em formas móveis, em um plano de consistência. É o ritornelo que cria o plano, pois ao escapar de forças territorializadas, improvisa-se. Improvisação é criação, “é ir ao encontro do Mundo, ou confundir-se com ele”. (DELEUZE; GUATTARI, 2012, p. 123) Já que a luta dessas forças vivas constituem componentes de passagem e são necessárias ao movimento contínuo ou ao ritornelo, que pode acontecer ou não. "Vai e volta-se, e quando se volta o ponto de partida deslocou-se. A improvisação é um ritornelo. A improvisação é criação” (GIL, 2008, p. 136). O eterno retorno, trazendo o mundo das diferenças, uma potência de afirmar.

\title{
Encontros
}

Nossos encontros com o Cefapro/MT foram exercícios do conter-se, do não-julgar, do não-significar, já que os encontros só se tornam encontros quando são recebidos e retribuídos à altura. Improvisação. Improvisar o cuidado com os encontros. Acolher a estranheza do imprevisível. Cuidar dos encontros e deixar esse imprevisível acontecer. Manusear e deixar as diferenças aflorarem. Ritmo. Um trabalho do transformar o saber em sabor. Saborear os 
encontros. Estar no meio. Estar no jogo ${ }^{4}$. Presente. Agora. Investimento necessário que nos convoca a parar e (re)parar nas forças vivas que nos atravessam. Encontrar-se é utilizar essas forças de tal forma que possam abrir uma brecha, uma ferida. Manter aberta a ferida é manter o encontro vivo como matéria para uma possível (re)existência, pois "a ferida é algo que recebo em meu corpo, em tal lugar, em tal momento, mas há também uma verdade eterna da ferida como acontecimento impassível, incorporal” (DELEUZE; PARNET, 1998, p. 79).

É como se a ferida já estivesse lá antes de nascermos e precisássemos estar à altura do acontecimento quando o encontrássemos. É uma questão das relações entre velocidades e lentidões. Deste modo, quando se chega aqui, no encontrar-se, não há mais o que fazer ou dizer; há apenas o viver e o habitar o encontro, descobrindo o que deve ser acionado. Confiar no acontecimento, no fazer juntas/os. O encontro é convocado por presença, por pertencimento, pela afecção convocada. "Um encontro é talvez a mesma coisa que um devir ou núpcias" (DELEUZE; PARNET, 1998, p. 14). Uma combinação frágil, mas com uma potência de vida que se afirma com uma força ímpar que transforma a paisagem, embora não seja possível dizer quando começou essa transformação. Confiança. Movimentos. Afectos.

Para manter a ferida aberta ou para mantermos o encontro vivo, apostamos na criação coletiva. Apostamos no ritornelo. Fomos criando coletivamente motivos para o desencadeamento do ritornelo, que deveio formação-ritornelo. A formação-ritornelo extrapola o território do Cefapro/MT, indo ao encontro de outros territórios construídos e habitados por cada um/a de nós, professoras/es-formadoras/es.

A matéria para a construção do encontro com a formação-ritornelo começou a ser gerada ainda em 2009, quando nosso primeiro encontro aconteceu, ainda que não soubéssemos disso. Naquela época não tínhamos consciência de onde estávamos adentrando, no que se refere às questões formativas, embora muitas/os de nós já estivessem presentes no Cefapro/MT há mais tempo. As angústias, os medos e as incertezas eram as mesmas.

$\mathrm{Na}$ construção desse caminho, muitas/os das/os componentes do grupo nos deixaram, assim como outras/os adentraram. Algumas/ns de nós, passeamos por diferentes (com)posições dentro da instituição, ocupando cargos de direção ou coordenação de formação, o que diferencia nosso olhar. Nesse percurso também foram realizadas várias pesquisas, algumas publicadas e academiadas, outras permaneceram na marginalidade. Ficamos durante esse bloco de espaço-tempo ensaiando e inaugurando novos modos de

\footnotetext{
4 “O jogo ideal, como Deleuze o desenvolve, é sem regras, sem vencedor e sem vencido. Ele é, antes de tudo, acaso, heterogeneidade” (LINS, 2008, p. 58). O jogo aqui é vida, pensamento, criação, improvisação.
} 
estarmos juntas/os, sempre no desejo de construção de uma formação que fugisse dos modelos habituais com os quais estávamos envolvidas/os, pois nossa singularidade requeria uma formação também singular. A inquietação provocada por essa formação-modelo e a ânsia da construção de uma formação-outra nos moveu para os encontros de agora. Um movimento cheio de percalços, de territorializações e desterritorializações, de medos e angústias, de alegrias e tristezas, de gritos e silêncios, de (re)paragens, de resistências e (re)existências. (Re)construção de mapas. Mapas e (re)existências que nos permitiram chegar aqui, no agora, no encontro com a formação-ritornelo.

No encontro de agora somos doze. Doze professoras/es-formadoras/es, que habitam diferentes territórios, ora na coletividade, ora em pequenos grupos, ora com outros grupos, ora solitariamente e ora nos encontramos no território chamado Cefapro/MT, nem sempre todas/os juntas/os. No encontro de agora procuramos preservar nossa heterogeneidade, pois pertencemos a diferentes áreas do conhecimento e temos diferentes ocupações dentro/fora do Cefapro/MT, o que nos faz embarcar em diferentes linhas de composição.

Somos da área das linguagens, códigos e suas tecnologias (língua portuguesa); da área das ciências humanas e suas tecnologias (história, geografia, filosofia); da área das ciências da natureza e suas tecnologias (biologia), da alfabetização (pedagogia), além das modalidades/especificidades de educação de jovens e adultos, educação do campo, tecnologia educacional e diversidade na educação básica. Somos também diretora e coordenadora de formação. Somos doze professoras/es-formadoras/es que nos dispusemos a nos encontrar e a nos desnudar, querendo ultrapassar o conceito da palavra formação, transbordar a forma, sair das hierarquizações e das classificações enclausuradas dentro dessa palavra tão desgastada na educação. De tal modo nos dispusemos a nos encontrar para uma formação sempre por vir, através da circularidade do ritornelo.

Nesse sentido, na perspectiva do acontecimento, os encontros com as/os professoras/es-formadoras/es, com o Cefapro/MT e com a possibilidade da construção de um plano de composição de nossa própria formação, realizamos, no segundo semestre do ano de 2014 e no ano de 2015, a concretização de sete encontros presenciais e uma multiplicidade de encontros virtuais que se estenderam para 2016 e ainda estão presentes no agora.

Nosso primeiro encontro foi recheado de expectativas. Enchentes de informações expressas em uma verborragia desnecessária. Necessidade inútil de justificativa, de explicação de uma coerência inexistente, laços que teimavam em não se construir. Olhares interrogantes. Foi o encontro das (des)cisões, de decidir e (des)cindir o como fazer. 
Decidimos fazer com. Decidimos nos desnudar, por isso nessa cartografia não há pseudônimos. Decidimos também filmar. Filmamos todos os encontros, o que nos permitiu a excitação da produção da dança ao vivo, mesmo sabendo que não era/é seguro, e nem há uma formação pronta para ser descoberta, mas para ser criada e conquistada no trabalho cotidiano com o Cefapro/MT. Sabedoras/es também de que não há coleta de dados, mas produção. Produção cartográfica. Produção de mapa móvel. Construção coletiva momentânea. Construção de ferramentas. Mapeamento do experimentável, não sem a angústia e o medo de os processos investigativos escaparem por entre os dedos, de a atenção não ser suficiente. Devido a isso temos clareza de não termos cartografado tudo, somente algumas cenas, algumas conversas, já que além de nossas limitações, a linguagem escrita também não nos permite expressar todos os afectos e movimentos e repousos. O enunciado ainda é mecânico e, muitas vezes, caímos na vala das explicações e interpretações, mas também reconhecemos as singularidades da criação coletiva, da disposição para. Inventar uma formação com, essa era a proposta: a invenção de um devir-formação; a construção da consciência de um ritornelo com a formação, com professoras/es-formadoras/es, com o Cefapro/MT.

Nos encontros, preferimos trabalhar com rodas de conversas e jogos ${ }^{5}$, sempre recheados de música e poesia. Apostamos no acontecimento, em encontros-formação mais leves, menos formatados, querendo ultrapassar a perspectiva que tínhamos de encontros formativos propriamente ditos. Então trouxemos para os encontros: vídeos com poesia e música, fragmentos de textos, instrumentos musicais, jogos (Tangram ${ }^{6}$ e Jogo das Perguntas ${ }^{7}$ ). Composição de heterogêneos. Com a ajuda dessas ferramentas cantamos, jogamos, fomos musicistas; também compartilhamos nossas angústias, medos, paixões, desejos. Medo/desejo de estar ali. No agora. No encontro. Com as ferramentas e as sensações convocadas construímos os encontros. Construímos nossa formação-ritornelo com o Cefapro/MT.

As ferramentas escolhidas para a construção dos encontros são fruto de um querer convocar sensações, um desejo de afecção. Um desejo de sentir as linhas de forças que nos atravessam. Um desejo de ensaiar uma nova forma de estarmos juntas/os com o processo formativo, porém sem o fantasma da formação-modelo. Por isso as ferramentas também se

\footnotetext{
${ }^{5}$ Aqui estamos nos referindo aos jogos-ferramenta dos encontros.

${ }^{6}$ O Tangram é um quebra-cabeça chinês que contém 7 peças ( 2 triângulos grandes, 1 triângulo médio e 2 triângulos pequenos, 1 quadrado e 1 paralelogramo) com as quais é possível montar uma infinidade de figuras.

${ }^{7}$ Segundo Eugénio e Fiadeiro (2014, p. 285) "é um jogo constituinte do Modo Operativo AND, que é um sistema de ferramentas-conceito e conceitos-ferramenta de aplicabilidade transversal à arte, à ciência e ao quotidiano para a tomada de decisão, a gestão sustentável de relações e a criação de artefatos".
}

Quaestio, Sorocaba, SP, v. 19, n. 2, p. 437-454, ago. 2017. 
constituíram em improvisações. Ferramentas estas para despertar práticas de atenção. Atenção à potência de nossos processos formativos sem o peso da obrigatoriedade que nos faz repetir o já previsto, querendo desenhar novos mapas formativos, embora todos os nossos medos e angústias estivessem presentes, pois na fuga sempre encontramos tudo aquilo de que fugimos. Deste modo, quando menos esperávamos, nos deparávamos com os fantasmas da formaçãomodelo, com aquilo que nos faz segui-la.

Três dos sete encontros foram instalados através de rodas de conversas, desencadeadas pelos questionamentos e pela improvisação. Conversas com a formação. Conversas com professoras/es-formadoras/es. Conversas com o Cefapro/MT. Os encontros com as rodas de conversas não foram realizados ordenadamente, sendo estes intercalados pelos encontros compostos pela ferramenta-jogo (três encontros), também desordenados. Além desses, realizamos um encontro com a música, o qual aconteceu no meio destes outros.

Os encontros com as rodas de conversas eram iniciados e recheados por trechos de poesias ou músicas, ou ainda poesias musicadas, ou fragmentos de textos que nos convocassem às novas e (im)possíveis sensações. Querendo sair da tradição-modeloformativo de leitura de textos acadêmicos, querendo explorar o que já habita em nós. Querendo mais sabor do que saber.

Com os encontros também surgiram conflitos/atritos, pois a proposta era ousada. Será que nossos encontros se concretizavam como formação? O que é uma formação ou um encontro formativo? Buchichos. Burburinhos. Literalmente abandono de encontros. Não comparecimento ou não comparecimento parcial, pois o desejo e a curiosidade para com as conversas eram inevitáveis. Um chegar no meio era fatal. Um querer que rejeita. Dificuldade de conversar com. Dificuldade de agir em prol da formação como afecto e não como construção de lideranças. Domínio de egos. Alianças.

Eu preciso de mais. Vamos ficando exigentes conosco mesmo (Eliane).

Eu acredito que as mudanças não acontecem porque nós não estamos preparados para a liberdade de construção, a gente não sabe como lidar com isso (Rosi).

Se cumprirmos todas as regras não dançamos nunca (Luiza).

Conversamos muito com nossa (in)(en)formação acostumada, mecanizada, que vicia corpos e mentes (aquela com a qual estávamos mais habituadas/os), mas também reconhecemos nossas linhas de fissura, abrindo feridas, transbordando o território e indo ao encontro de um devir-formação, das alianças. Singularidade. Contágio. Blocos de criação. Conversas com, e não conversação ou debate entre professoras/es-formadoras/es, pois não é 
uma questão de domínio, já que este é dado pelo próprio encontro. Composição de corpos. Alianças. Combate ao ego que ainda quer competir, que ainda quer construir identidade. Precariedade. Experimentação do inevitável, embora em muitos momentos, a representação teimava em aparecer, o saber queria falar mais alto e a preocupação com uma formação que desse respaldo acadêmico, que se concretizasse em certificados e diplomas, entrava em pauta. Em vários momentos o peso do modelo-de-professor/a-formador/a nos incomodava. Como viver juntas/os em um mundo que é representado pela segmentação e pelas dualidades? Como viver o agora, o acontecimento? Podemos viver sem ideias e com o que há? Essas perguntas desligam a programação padrão, que requer sempre novas ideias na criação de uma realidade ideal colonizada, como nos ensinam Fernanda Eugénio e João Fiadeiro (2014). É um exercício do parar, (re)parar e reparar. Atuação coletiva, na tentativa da construção de um jogo do viver juntas/os, que provocou mais sensações que interpretações. Um jogo que nos fez agir juntas/os, ofertando nossas obras no encontro. Sem respostas prévias, sem ideias, apenas saboreando o momento. Os encontros nos possibilitaram nos olharmos enquanto gente, enquanto profissionais que trabalham o coletivo. Quanto esta relação aguenta/aguentará? Quanto tempo o coletivo se sustentará? Questionamentos que perambularam nossa mente na experimentação com os encontros, que nos fizeram pensar sobre nossa relação com a formação, com o Cefapro/MT.

Fica evidente que, em muitos momentos a gente está junto, mas estamos separados. Agimos separadamente. Esse enxergar de outra maneira é muito difícil (Sirley).

Abrir para as possibilidades. Não existe nada definido. É permitido a ação dos diferentes, de cada particularidade (Hermógenes).

Interessante a gente se perceber (Rosirene).

Observar é muito importante (Luiza).

Às vezes estamos só fazendo nossas coisas e esquecemos do outro, esquecemos que o trabalho é coletivo. É tão sério isso, tão assustador, que a gente percebe a grande dificuldade de cada um de nós quando tem que ouvir o outro, prestar atenção no outro (Rosi).

Quando a gente olha e está na velocidade acostumada só vemos aquilo que estamos acostumados a ver (Anderson).

Exercício do parar, reparar e (re)parar. Exercício do fazer com. Exercício do aprender a conviver. Exercício de inventar novos estilos de viver juntas/os com a formação. Fragmentos que estiveram presentes durante os encontros. Percepções, afecções, devaneios, formação. Confiar na potência do encontro, confiar em nós. Entrega. Fazer com. Fazer de outra forma porque aquela não dava mais conta de nossos pensamentos. 
Quando a gente fala da novidade que é pensar de uma outra forma, fazer seria um segundo passo. Não dá para pensar de uma outra forma e fazer do mesmo jeito (Anderson).

Os três encontros construídos através da ferramenta-jogo (tangram e o jogo das perguntas) foram utilizados como ferramenta-exercício de um modo outro de viver juntas/os, mas com a possibilidade de um (re)começo quando necessitássemos, sem a responsabilidade do acontecimento real. Exercícios de simulação. Um laboratório do viver juntas/os. Um laboratório com a formação.

No encontro com o Tangram, este foi apresentado virado de cabeça para baixo na mesa que abrigava a roda de conversa e no verso de cada uma das peças colocamos um questionamento. Cada um/a de nós pegava uma peça e íamos montando um novo desenho, um novo mapa, circunscrevendo nossas ações no Cefapro/MT. Os questionamentos contidos nas peças eram: 1) Onde está o coletivo? 2) Qual é a dor e a delícia de estar no Cefapro/MT? 3) Como vim parar aqui? 4) Consigo comparar quando cheguei e como estou agora? 5) Como experimento com o Cefapro/MT? 6) Desejos? 7) Espaço de formação?

Não segue o que eu planejei. O movimento muda aquilo que você quer fazer (Rosi).
Quando você coloca a pessoa ao seu redor é também um aprisionamento (Maria Auxiliadora).

normal a existência de pequenos grupos, em qualquer ambiente de trabalho isso acontece (Luiza).

Muitas vezes não estamos interessados em sair da caixa, da instituição, em enfrentar ou questionar as regras, porque estamos muito ocupados em cumpri-las (Sirley).

Fiquei apavorada (Eliane).

As (com)posições, as posições(com) provocaram desvios, pois não estávamos/estamos à procura de respostas, nem de histórias, nem de caminhos já trilhados ou conceituações. Um exercício de enxergar com a formação. Um exercício do cuidado com a formação. Uma formação-acontecimento. É um transformar minha vontade pessoal em uma potência impessoal, extrair disso o acontecimento-encontro com professoras/es-formadoras/es.

São as escolhas: enfrentar ou voltar para a casca? (Elza).

Não é que a gente não se vê como classe de professores, classe trabalhadora, como grupo que também é excluído. Não se trata de não querer se ver, mas são situações que nos levam a pensar assim. Inocência (Osvaldo).

Partimos para uma aventura em busca do ritmo, que deveio estilo. Não sem (re)existências. Na ânsia de uma dança que se estendeu além e aquém das fronteiras e limites do mapa-decalque, da cópia. Territorialização-desterritorialização-reterritorialização, no ritmo 
do ritornelo. Todas/os juntas/os cavoucando nossos próprios buracos, nossas tocas, remexendo e perturbando forças e controles.

Outro encontro foi uma conversa musicada. Sensações convocadas por performance e canções. Performance do ser mulher na educação, do estar presente profissionalmente, do encontrar nosso lugar. O em casa do ritornelo. Um movimento feminista. Amizades sinceras transcritas em palavras e canções. Canções inventadas. Canções tocadas. Canções convocadas pela saudade. Trazidas pelas histórias contadas e rememoradas. Canções de agora. Canções que expressaram nossas dores e delícias ${ }^{8}$. Emoções contidas e extrapoladas. Isto é formação? Cantamos. Dançamos. Choramos. Inventamos novas (im)possibilidades de estar juntas/os. Desterritorializamos a formação.

Esses encontros trouxeram muitos elementos novos, uma quebra das regras, pois às vezes, conseguimos pensar diferente, mas não conseguimos por em prática um fazer diferente. Agora conseguimos (Hermógenes).

A educação é isso. Reconstruir o tempo todo. Inventar (Luiza).

Importante nos percebermos, perceber o como nos tornamos o que somos. Os encontros nos fizeram lembrar coisas que estavam escondidas (Rosi).

Somos fruto do que conseguimos ser, fruto de nossas velocidades e lentidões conquistadas, daquilo que não nos deixamos aprisionar, daquilo que experimentamos. Vetores de forças que provocam sensações, abrindo feridas que possibilitam ver outras coisas, que possibilitam o trabalho com elas, que possibilitam o esquecimento e a transformação das mesmas em força desterritorializante. Encontros que nos possibilitaram lutar com conceitos e (pré)(pre)conceitos.

As pessoas vão falar que você é menos porque é negro, porque é mulher, porque é gay. E se você acreditar, você cai no jogo deles (Anderson).

Os experimentos traduzidos em encontros refletiram o como manejamos, ou nos deixamos sermos capturadas/os pelas linhas de forças que nos atravessam. Na aprendizagem de transformar essas forças em intensidades que nos impulsionam para a vida. A velocidade ou a lentidão conquistada. Aquilo que tem força suficiente para nos colocar em movimento. Força o suficiente para nos fazer dançar com nossas misérias, com as forças convocadas, com as sensações provocadas.

Outros dois encontros foram construídos com o jogo das perguntas. Jogo este, onde tudo é construído jogando-se. O tabuleiro é delimitado de acordo com o espaço que temos, as

\footnotetext{
${ }^{8}$ Roubadas da música Dom de Iludir de Caetano Veloso.

Quaestio, Sorocaba, SP, v. 19, n. 2, p. 437-454, ago. 2017.
} 
regras são construídas em seu decorrer e as peças são "tralhas" como nos ensinou Fernanda Eugénio, ou seja, quaisquer objetos que temos em mãos. Nós utilizamos objetos pedagógicos existentes no Cefapro/MT, assim como objetos pessoais.

Um jogo em que o espetáculo é concebido enquanto "condição", e não enquanto "condicionante". Um jogo cujas regras emergem enquanto se joga, sustentadas na "consistência" (e não na "coerência") do que se vive e do que a partilha. Um jogo que só acontece porque deixamos de nos ocupar em "saber por que" e nos concentramos em "saborear o que", desdobrando "o que sabe" o acontecimento (EUGÉNIO; FIADEIRO, 2014, p. 287).

As primeiras jogadas foram extremamente individuais, queríamos regras e lideranças para seguir. Busca incessante de modelos. Acidentes ignorados. Jogadas excessivas sem parar e (re)parar.

Pareceu-me sem coletividade (Rosirene).

Esse coletivo é só um faz de conta? Quando a coisa aperta prevalece a ideia de um ou de outro? (Rosi).

Se não for do meu jeito não quero mais, não vou mais. É isso? (Eliane).

Foi um disparar coletivo! Necessidade de (dês)parar até encontrar o ritmo para responder os encontros à altura. Entre as velocidades e lentidões conquistadas. Quanto tempo a relação aguenta? Quanto tempo aguentamos antes de criar nosso próprio mundo? Resistências. (Re)existências. Conjunto de inquietações à procura de ritmo. (Des)territorializações (im)possíveis. Construção de mapas para conviver. Para estar presente no grupo. No agora. Gestão de um plano comum. Cuidado coletivo com a formação. Cuidado com o encontro.

O problema é que, às vezes, a gente olha só de um ângulo. Quando se olha de outros ângulos, você cria outras situações (Maria Auxiliadora).

Eu tenho que mudar para eu ficar aqui. Tenho que dar continuidade ao mundo que entrei (Rosirene).

Agora trabalhamos mais coletivamente, prestamos mais atenção no outro (Rosi).

Exercícios com (im)possíveis modos de atenção. Exercício de manter o encontro vivo através do cuidado com o plano comum, circunscrito pelo nosso tabuleiro. Sem lideranças. Controle contínuo do ego. Querendo alianças. Nos descobrindo...

Vamos fazer uma auto-análise. As nossas dificuldades de grupo apareceram: quem é mais individualista, quem não consegue produzir em grupo, quem quer passar na frente do outro, quem quer mexer no trabalho do outro, quem quer estar sempre em evidência (Rosi). 
No laboratório, o jogo nos permite o fazer com, exercitando práticas de atenção que podem reverberar no cotidiano, na vida, na formação. Porém temos consciência de que a construção da formação-ritornelo só pode se concretizar através das revoluções moleculares que vivem em nós. Isto porque a singularidade da gestação de nossas ações caminha por conexões sempre novas, sempre próprias, apesar da tentativa de cooptação através das normas e modelos instituídos. Exercício contínuo de práticas de atenção.

Aprender tem muito a ver com sensibilidade (Anderson).

As intensidades são diferentes, mas os movimentos são sempre possíveis (Eliane).

Revoluções moleculares, sensações e afectos que convocam um devir-formação, que lutam com a formação-instituída, pois é sempre um movimento de dupla captura. Sempre no perigo do aprisionamento. Um entre-lugares. Meio. Estar no meio é se constituir como meio. Experimentar com o meio. Tornar-se a própria coisa. Ser a coisa. Tornar-se a própria formação. Ser a formação ou ser digno dela, como nos ensinam Gilles Deleuze e Claire Parnet em seus Diálogos (1998, p. 79) "não ser inferior ao acontecimento, tornar-se o filho de seus próprios acontecimentos".

Assim estar no Cefapro/MT com as pessoas que o compõe, é inquietante, angustiante, porém somos sabedoras/es da existência das revoluções moleculares e cósmicas que vivem em nós, forças que atuam nos movimentos de territorialização-desterritorializaçãoreterritorialização, em uma constante luta entre as forças do caos, forças terrestres e as forças cósmicas. Buscas constantes por frestas, gretas, rachaduras que convocam sensações e afectos, formando um plano de composição. Composição com professoras/es-formadoras/es, com novas e (im)possíveis (com)posições de formação. Posições com a formação.

O trabalho é o cuidado com a formação. Todas/os juntas/os cuidando da formação na sua molecularidade, nas suas entranhas. Essa é a revolução molecular que nos embarcou nas linhas de errância e nos fez experimentar o desconhecido. Improvisar. Criar. Acordar, cortar a carne e (re)abrir as feridas. Manter o encontro vivo, manter a ferida aberta.

Tem coisas que estavam tão silenciadas dentro de mim, mas que eu nem sabia o que era, mas queria (Rosirene).

Eu experimento com a nossa convivência, seja ela nos momentos formativos, nossos encontros, estudos. O nosso experimentar é um desafio, um aprendizado (Beatriz).

O Cefapro/MT é um território paradoxal, que se junta com outros territórios contidos em nós, onde as coisas acontecem ou nos paralisam. Onde os planos se imbricam, nos 
aceleram, nos dilatam, nos alongam, provocando blocos de sensações, nem sempre alegres, pois estamos sempre na fronteira, na iminência do perigo, da captura.

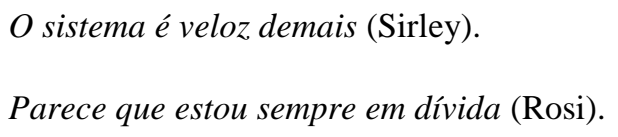

Como espaço paradoxal, o Cefapro/MT é lugar de luta, resistência, (re)existência, mas também lugar de criação. Utilizarmo-nos da potência desse paradoxal é criar novas possibilidades formativas, é tornar o Cefapro/MT um espaço privilegiado para criações e possibilidades. Possibilidades para o desencadeamento do movimento-ritornelo. Possibilidades para o desenvolvimento da formação-ritornelo com as/os professoras/esformadoras/es, com a formação, com o Cefapro/MT, através de encontros. Promover encontros que façam vibrar as sensações, os afectos, que produzam ações de matilha, de multiplicidades.

\footnotetext{
Quando sinto desejo de ir além eu vou! (Luiza).

Aquilo que me inquieta me leva a lutar (Sirley).

Nossa luta é pela formação (Beatriz).

A construção do conhecimento é uma luta (Osvaldo).

Existem muitos caminhos formativos, não existem percursos certos ou errados, apenas caminhos (Maria Auxiliadora).

Cada um produz de onde a sua condição permite (Rosirene).
}

A percepção e a consciência de que vivemos em luta, de que não existem caminhos certos ou errados, nos fazem embarcar em certas linhas de errância capazes de intensificar nossas forças e acionar a formação-ritornelo, com desejo, ética e alianças. Contágio. Percepção de que podemos enfrentar nossas culpas e iniciar uma revolução molecular que nos permita (re)criar nosso cotidiano, transformando nossas ações formativas na formaçãoritornelo. Com nossos encontros embarcamos em linhas de fuga, as quais nos conduziram ao novo, ao experimento com a formação. Juntas/os! Nossas perguntas ainda continuam vivas. Não estávamos à procura de respostas, mas na busca de cartografar uma formação intensa, 
forte, que tem força suficiente para se transbordar e capturar as forças cósmicas. Um devirformação-consistente. Um eterno retorno como ritornelo capaz de capturar as forças não visíveis e não pensáveis do Cosmo, sempre no cuidado de não sermos capturadas/os e cairmos nas garras da reprodução, mas é um risco.

As perguntas continuam intensas, fortes. A formação-ritornelo continua viva. A ferida continua aberta. Estamos em plena experimentação do encontro agora. Não sem resistências e (re)existências. Não sem atritos. Burburinhos. Incertezas. Na tentativa de (com)pôr mapas com as/os professoras/es-formadoras/es, com a formação, com o Cefapro/MT.

\section{O que ficou?}

O acontecimento. Onde estão os múltiplos questionamentos que nos puseram em movimento cartográfico? E aqueles que nos impulsionaram durante o processo? Aqueles que possibilitaram a montagem e a desmontagem de mapas? Todos transbordados e transformados em multiplicidades. Questionamentos (de)compostos na circularidade do ritornelo. Nenhuma resposta. Nenhum caminho pronto, mas o desejo de continuar caminhando, de continuar se encontrando. Conscientes de que o plano de consistência pode gerar a formação não pessoal que nos atravessa, o que nos fará embarcar no eterno retorno, produzindo diferenças naquilo que se repete. Exercícios de atenção. Práticas de atenção aos fluxos formativos, que ritmadamente nos levam para outros mundos possíveis.

Os encontros me deixaram sem chão, preciso me desconstruir para estar presente nos processos formativos novamente (Sirley).

Os encontros, enquanto criação podem ser realizados em qualquer paisagem (Maria Auxiliadora).

Eu vivi muito. Aprendi muito com nossos encontros. Nos conhecemos enquanto humanos (Luiza).

Com nossos encontros vi um outro ângulo da formação (Beatriz).

Temos embarcado em processos formativos muito frios, mecânicos. Em nossos encontros não (Rosi)

Os encontros vieram nos ajudar a pensar de uma outra maneira. Vieram nos falar das fugas. Vieram nos falar que somos outros. Que crio personagens quando me encontro (Rosirene).

Os encontros produziram diferenças (Hermógenes).

Com os encontros estamos mais atentas/os, cientes da existência da formação-ritornelo com o Cefapro/MT, mas há sempre um risco. Risco de sermos capturados pela formaçãomodelo. Risco de nossa potência de agir ser minada. Risco da interpretação e da representação falar mais alto, pois como nos ensinam Gilles Deleuze e Claire Parnet em seus Diálogos... 
Não é fácil ser um homem livre: fugir da peste, organizar encontros, aumentar a potência de agir, afetar-se de alegria, multiplicar os afetos que exprimem ou envolvem um máximo de afirmação. Fazer do corpo uma potência que não se reduz ao organismo, fazer do pensamento uma potência que não se reduz à consciência (DELEUZE; PARNET, 1998, p. 75).

O acontecimento da cartografia possibilitou-nos abrirmos conversa com nossos processos formativos dentro/fora do Cefapro/MT, explorando também nossa potência de agir. Os encontros ainda vivem em nós. Só precisamos embarcar neles. Experimentar com eles. Querer o acontecimento, pois o que conta em um caminho, em uma linha, é sempre o meio. Sempre estamos no meio de alguma coisa. Entre latitudes e longitudes. Porém há a necessidade do parar, reparar e (re)parar. (Des)parar para não disparar. Necessidade de encontrarmo-nos entre nossas velocidades e lentidões.

O desafio é permanecer no movimento. No meio. No encontro. Permanecer no movimento-ritornelo. No ritmo do ritornelo. Na formação-ritornelo. Por isso experimentemos! Experimentemos nos encontrar e encontrar algo.

Nós encontramos a poesia...

Entrar na Academia já entrei, mas ninguém me explica por que essa torneira aberta neste silêncio de noite parece poesia jorrando [...]

Manoel de Barros (2010).

\section{Referências}

BARROS, Manoel de. Poesia completa. São Paulo: Leya, 2010.

DELEUZE, Gilles; GUATTARI, Félix. Mil platôs: capitalismo e esquizofrenia. 2. ed. São Paulo: Editora 34, 2012. v. 4.

DELEUZE, Gilles; PARNET, Claire. Diálogos. São Paulo: Escuta, 1998.

EUGÉNIO, Fernanda; FIADEIRO, João. Jogo das perguntas: o modo operativo "and" e o viver juntos sem ideias. In: PASSOS, Eduardo et al. (Org.). Pistas do método da cartografia: a experiência da pesquisa e o plano comum. Porto Alegre: Sulina, 2014.

GIL, José. Ritornelo e imanência. In: LINS, Daniel Soares; GIL, José. (Org.). Nietzsche/Deleuze: jogo e música. Rio de Janeiro: Forense Universitária/Fortaleza/CE: Fundação de Cultura, Esporte e Turismo, 2008.

LINS, Daniel Soares. Deleuze: o surfista da imanência. In: LINS, Daniel Soares; GIL, José. (Org.). Nietzsche/Deleuze: jogo e música. Rio de Janeiro: Forense Universitária. Fortaleza/CE: Fundação de Cultura, Esporte e Turismo, 2008.

LINS, Daniel Soares. Mangue's school ou por uma pedagogia rizomática. Educação \& Sociedade, Campinas, v. 26, n. 93, p. 1229-1256, set./dez. 2005. Disponível em: <http://www.cedes.unicamp.br>. Acesso em: 28 out. 2016.

ZOURABICHVILI, François. O vocabulário de Deleuze. Rio de Janeiro: Relume Dumará; Sinergia; Ediouro, 2009. 
Marcia Regina Gobatto - Universidade Federal de Uberlândia. Uberlândia | MG | Brasil. Contato: marciagobatto@ hotmail.com

Daniela Franco Carvalho - Universidade Federal de Uberlândia. Uberlândia | MG | Brasil. Contato: danielafcj@gmail.com

Artigo recebido em: 2 maio 2017 e aprovado em: 2 jul. 2017. 